\title{
Albania vs. Balkan's Countries as Comparative Analysis of the Human Development Index
}

\author{
Dorina Ciko \\ Economic Department, University of Gjirokastra, Albania \\ Email:dorinaciko@yahoo.com
}

\section{Doi:10.5901/mjss.2015.v6n4s3p311}

\begin{abstract}
During the last decades, the central focus of economists was growth of incomes in the early 1990s, the focus shifted towards the quality of life and development strategies being oriented from production to welfare improvement. In recent years a large literature has been developed regarding indicators of welfare and life quality. The Human Development Index (HDI), elaborated by the United Nations Development Program in 1990, was an indicator of life quality and a good proxy indicator of welfare. Human Development Index provides a better alternative to measure countries overall achievements in their social and economic dimensions. In this paper, the theoretical literature review provides a brief history of the human evolution and development aspects. This paper examines the dimensions of Human Development Index like life expectancy, education and income index in Balkan countries. The aim of this paper is to found out the trend of human development in Balkan countries and to make a comparison of various human development aspects in Albania comparing it with other countries in the region. This paper is completed through qualitative methods. Finally the paper will be closed with some conclusions.
\end{abstract}

Keywords: Human development, HDI, well-being, Balkan countries

\section{Introduction}

Whenever we think about development, usually we tend to think about economic development. The fundamental difference between economic and human development is that economic development focuses entirely on income growth, whereas human development believes in expanding all aspects of human life such as social, economic, cultural, political aspects. For many decades, GNP- Gross National Product has been considered as the only measure of development and welfare. Economic growth of a country is measured by the change on GNP which is still the most widespread measuring tool. High rates of economic growth cannot be translated automatically to the improvement of human welfare. Many countries have registered improvement in human welfare even though modest economic growth. In this way, many questions arise about the nature, distribution and quality of economic growth. Using GNP as a measuring tool for the economic performance and social progress does not include many of the multidimensional aspects of development such as poverty, income inequalities, unemployment, and inequality in access to goods and public services such are health, education, etc (Nayak, 2013). In this way it is necessary to use indicators that give us a clear view of these aspects because GNP is not sufficient to be a sole indicator of welfare because is focused in only one aspect of welfare. The quality of life also depends on non-economic factors such are health, social relations, environmental conditions, perceptions of the individual, etc (Stiglitz et al., 2009; Tresor-Economics, 2009). The main deficiency of measuring the development only from the economic aspects is concentration on the measurement of national product and aggregate income than people's entitlement and capabilities that generate these rights (Sen, 1984; Noorbakhsh, 1998).

In recent literature, human development is often described as the ultimate goal of the development process and economic growth but this is an insufficient measuring of general welfare. This debate has expanded definitions and development objectives but it is necessary to determine the relationship between human development and economic growth. Human development will have a significant effect on economic growth and to the extent that freedom and greater ability will stimulate the improvement of economic performance. Similarly, economic growth will increase human development to the extent that increase of income will enhance the range of choices and capabilities gained from families and governments (Ranis, 2004). So the development should be seen as an improvement of human needs and not as a growth of income (Nayak, 2013). Seers (1972) suggested that the development should be seen as an opportunity to create conditions for the realization of human potentiality. At the center of this process should be placed people and development should be based on their freedom, achievements and skills (Anand \& Sen, 1992) offering equal opportunities for all. This includes not only extension of capacities to offer more choices for current generations and to live in a healthy, productive and safer environment, but also ensuring that these elections will not restrict the opportunities available for next generations (HDR, 2014). In other words, economic performance and social progress will be measured in terms of sustainability, i.e. by measuring the welfare of next generations. 


\section{Human Development in a Historical Perspective - Review of the Literature}

For decades, GNP per capita is used to measure welfare. However, the use of this indicator was often criticized since the incomes are the only one aspect of welfare. The first criticism issue concerning about the use of this indicator can be found in the Report of the United Nations (UN, 1954), in which specific recommendations are made about the objections of using this indicator as a measuring tool of standard living. This was followed by a vast literature in the 1970s, for the use of socio-economic indicators as a measuring tool of developments such are health, education, employment, housing and basic human rights. Concepts such, as "basic needs", which are mostly geared toward human development, were on the focus of the debates about development policies (Hicks \& Streeten, 1979; Streeten et al., 1981; Noorbakhsh, 1998b). One of the earliest contributions to the development of a coherent conceptual framework for the inclusion of development social indicators was a project carried out by Raymond Bauer (1966) which provided a framework for the integration of analyzes which, until then, were undertaken independently by each other, e.g., analysis of the changes in health, education, transport, housing, employment, urban development and other sectors of public activity (Estes, 2012). Also, an early contribution on social development indicators has given UNRISD- United Nations Research Institute For Social Development where, in 1966 published a study of Living Index (LLI- Level of Living Index) including categories for physical needs: nutrition, housing and health; cultural needs: education, leisure, and security (Drewnowski \& Scott, 1966; McGillivray \& Noorbakhsh, 2004; Stanton, 2007). McGranahan in collaboration with UNRISD in 1972 created a General Development Index (GID- General Index of Development) which includes nine economic characteristics and nine social features to understand the stages through which poor countries must shift their efforts to achieve higher levels of social and economic development (McGranahan et al 1972; Hicks \& Streeten 1979; Stanton, 2007). They argued the necessity of the changes in the objectives of the development programs by proposing meeting basic needs as an attempt to move towards placement of the purely macroeconomic objectives with the human objectives (Hicks \& Streeten, 1979; Streeten et al, 1981; Noorbakhsh, 1998). Campbell, Converse \& Rodgers (1976) presented qualitative measurement including satisfaction as one of the measures of quality of life which until that time have been dominated only from objective measurement to evaluate changes in the development progress (Estes, 2012). Other subsequent attempts that shifted gradually goals of social and economic policy towards non-economic aspects of life are those of Morris (1979) who introduced the PQLI-Physical Quality of Life Index to measure social welfare and if a minimum set of human needs is being achieved from the poorest people of the world. Camp and Speidel (1987) introduced the HIS-Human Suffering Index, which included income, infant mortality, adult education and personal freedom, etc (Srinivasan, 1994; Stanton, 2007).

The latest attempt to assess the welfare and human progress is based on the use of a multidimensional measure which combines different indicators of socio-economic development. The most successful indicator and widely used since 1990 is the Human Development Index (HDI) which is elaborated by the United Nations Development Program (UNDP). The first report of Human Development is initiated by Mahbub ul Haq who has had a clear goal: "to shift the focus of economic development from the calculation of national income towards policies focused on people" (Haq, 1995). Human Development Report is one of the greatest contributions that reoriented the debate about measuring tool of economic development beyond the traditional perspective by defining human development as: "the ability of people to be free to expand human choices and to participate in decision-making issues that affect their lives" (UNDP, 1990; Adand \& Sen, 2000). Also, stressed that the available choices of people can be infinite and can change over time. Although, at all levels of development, three are the most important ones that lead to a long and healthy life, in gaining knowledge and better standard of living. HDI has played two key roles in the economy: First as a popular tool for human development as a new sense of wellbeing and secondly as an alternative to highlight the deficiency of other indices such as GNP (Streeten, 1994), advantages of HDI vs. per capita income indicator because the latter neglects the distributional aspects (Desai, 1993), as well as the inclusion of more aspects of human development (Haq, 1995; Noorbakhsh, 1998). HDI together with other indicators helps policymakers and professionals of development worldwide to assess trends in the advancement of human development and take public actions to fit the present and future economic and social conditions (Stanton, 2007).

\section{Methodological Framework}

The objective of this paper is to found out the trend of human development in Balkan countries and to make comparative analysis of various aspects of human development in Albania and comparing it with other countries in the region. In this paper are analyzed various aspects of human development in the Balkan region (with the exception of Kosovo, due to the limited resources of data) using data from Human Development Reports (1990-2014) published by UNDP for years that are taken into consideration. Descriptive statistical analysis gives an overview of recent developments of human aspects 
in the Balkan countries by dissecting the main contributors to the development such as life expectancy, education and standard of living.

\section{Analysis Results}

Although, since the beginning of the 1990 Balkans countries have been changed in different aspects such as social, economic and political aspects, they also have significant differences in terms of human development. The successive Reports of Human Development have shown that most Balkan countries have experienced improvement in human development. Advances in technology, education and income promise for longer, healthier and more secure lives (HDR, 2013). Since $1990 \mathrm{HDI}$ is one of the most important measuring tool of social and economic progress which measures the average achievements in a country in three key dimensions: a long and a healthy life, access to knowledge and a decent standard of living (HDR, 2014). HDI value ranges from 0 to 1 , where countries which have a score close to 1 are more developed. HDR 2014 (published by UNDP) included HDI rankings for 187 countries which are grouped into four categories related to human development: Very High Human Development when the value of HDI is greater than 0.8 , High Human Development when the value of the HDI is between 0.700-0.799, Medium Human Development when the value of $\mathrm{HDI}$ is between $0.550-0.699$ and Low Human Development when the value of the HDI is less than 0.550. World $\mathrm{HDI}$ value is 0.702 while the $\mathrm{HDI}$ value for Europe and Central Asia is 0.738 (HDR, 2014). In the Balkan countries that are taken into analysis has been an improvement for HDI values referring to the period 1990-2013. While all Balkan countries have registered improvement during this period, signs of a slowdown emerged after 2008, as measured from the growth rate of $\mathrm{HDI}$ values:

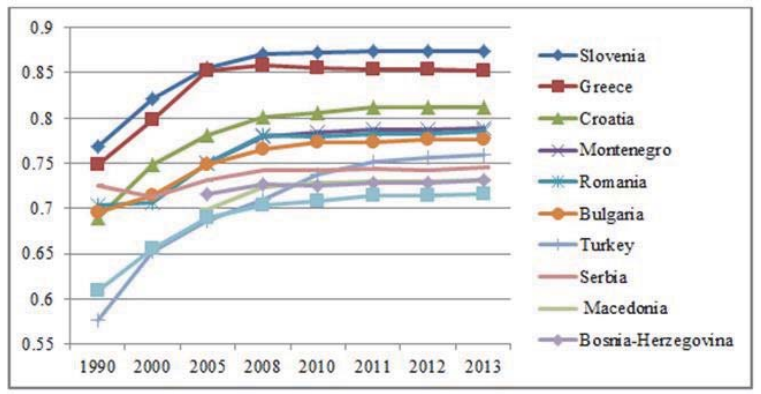

Figure 1. Trend of HDI during 1990-2013 (Source: UNDP)

Fastest pace of growth were recorded in the period 2000-2008 than in the years 1990-2000 (for Bosnia-Herzegovina, Macedonia and Montenegro there is no data for the HDI values for the period 1990-2005). During the period 1990-2000, Turkey has had the greater average annual growth of HDI by 1.34\% while in the period 2000-2008 there has been Romania by $1.33 \%$. However, signs of a slowdown were identified referring the average annual growth rate of HDI after 2008. So, most of the countries in the region have experienced a slowdown in growth rates of HDI after 2008 and this is connected with the global economic and financial crisis which seems to have had a wider impact. Thus, in the period 2008-2013 Turkey has had the greater average annual growth by $0.99 \%$.

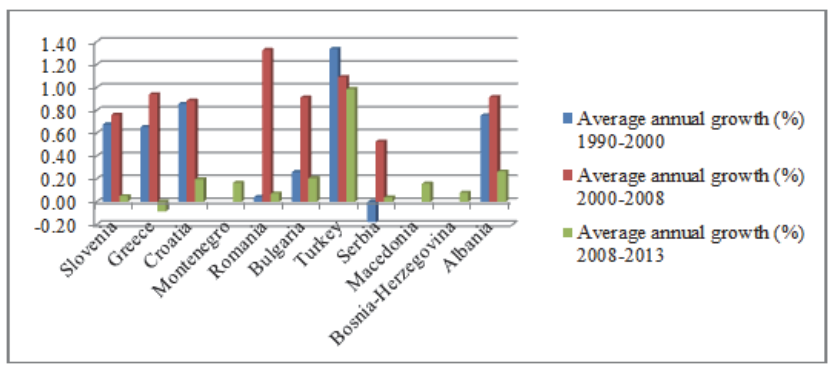

Figure 2. The average annual growth of HDI during 1990-2013(Source: UNDP) 
The list of countries in the region that have been taken in analysis is leaded from Slovenia, which is positioned in 25-th place with an index 0.874 , followed from Greece and Croatia where all three countries are part of countries with very high human development. Other Balkan countries that are taken into analysis such are Montenegro, Romania, Bulgaria, Turkey, Serbia, Macedonia and Bosnia-Herzegovina belong to the category with high levels of human development and are positioned over Albania which if we refer to the region is ranked the last with a HDI value of 0.716 .

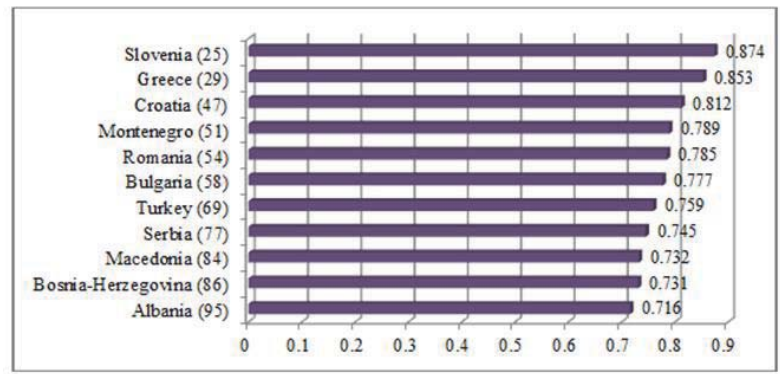

Figure 3. Human development ranks in Balkan region, 2013 (Source: UNDP)

The Human Development Index is composite index of achievements in human development. The HDI must be able to measure the basic dimensions of human development such are: to live a long and healthy life, to acquire knowledge and to have a comfortable standard of living. It includes three dimensions indices: LEI-Life Expectancy Index, El-Education Index and II-Income Index. Life expectancy of birth was chosen as an indicator of life expectancy; schooling and literacy as indicators of education; and GNI per capita expressed in Purchasing Power Parity as an indicator of standard of living.

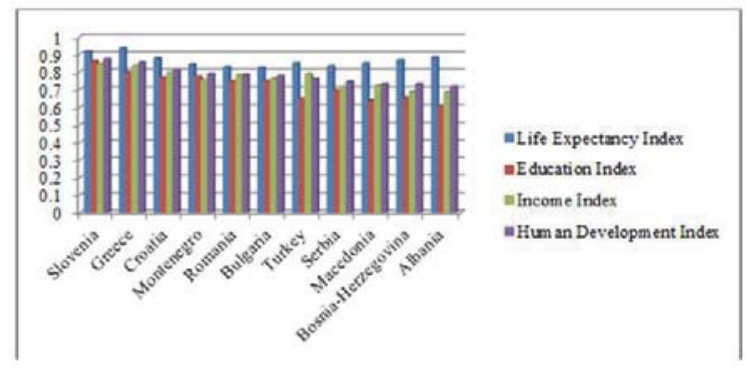

Figure 4. The dimensions of the HDI, 2013 (Source: UNDP)

In terms of Life Expectancy Index seems to have a significant improvement in this index. Greece has the highest value of this index by 0.935 , which is followed from Slovenia, Croatia and Albania. Meanwhile, Romania and Bulgaria have the lowest value of this index respectively 0.828 and 0.824 . The most basic indicator that measure if people have a long and healthy life is life expectancy at birth. If we refer to the period 1990-2013, all countries of the region have had a significant improvement in average life expectancy. This improvement is particularly associated with investments in the health of the citizens, in reducing infant and maternal mortality as well as new methods of treatment. In 2013 , Greece had the highest average life expectancy at birth with 80.8 years whereas the lowest was possessed from Bulgaria with 73.5 years. While about life expectancy at birth, Albania leaves behind many countries although it is the penultimate in the region for health expenditures which are about 6.3\% of GDP (Gross Domain Product). Greece has the highest health expenditure in the region around $10.8 \%$ of GDP.

If we refer to data for the period of time 1990-2013 the general trend of the Education Index has shown signs of improvement in all countries of the region. In 2013, Slovenia had the highest value of Education Index respectively 0.863 , which is followed from Greece with a value of 0,797. At the end of the list with the smallest value of this index of 0.609 stands Albania. Indicators used to measure the Education Index are the average years of schooling that adults (aged over 25 years) have spent in schools and expected years of schooling that children will spend with education in the whole 
life, where in 2013, Slovenia had the highest value of these indicators respectively to 11.9 years and 16.8 years. In the same period Turkey had the lowest value of average years of schooling of 7.6 years while Albania had the lowest value of the expected years of schooling of 10.8 years. Albania was ranked the eighth in the region in terms of average years of schooling by 9.3 years. Education and skills development are crucial to employment and productivity. Furthermore, although primary education is compulsory and free in Albania, the analysis reports of PISA (2009) showed a deficiency in human capital formation as indicated by high functional illiteracy of 56.7 per cent of adolescents in Albania. Functional illiteracy in this age is associated with difficulties in further education and future employment (Bertschy et al., 2008). Albania is among the last countries in the region on the percentage of the education budget against GDP by about 3.3\%. She leaves behind only Turkey, which gives only $2.9 \%$ of GDP in education. Slovenia leads the list of countries in the region which spends on education $5.7 \%$ of GDP and after that Croatia by $4.1 \%$.

Table 1. Trend of LEI, EI \& II, 1990-2013

\begin{tabular}{|c|c|c|c|c|c|c|c|c|c|c|c|c|}
\hline Countries & Indicators/Dimensions index & 1990 & 2000 & 2005 & 2006 & 2007 & 2008 & 2009 & 2010 & 2011 & 2012 & 2013 \\
\hline \multirow[t]{7}{*}{ Slovenia } & Life expectancy at birth (years) & 73.2 & 75.9 & 77.7 & 78 & 78.4 & 78.7 & 78.9 & 79.1 & 79.3 & 79.4 & 79.6 \\
\hline & Life Expectancy Index (LEI) & 0.819 & 0.861 & 0.887 & 0.893 & 0.898 & 0.903 & 0.906 & 0.91 & 0.912 & 0.915 & 0.917 \\
\hline & Mean years of schooling (years) & 10.9 & 11.6 & 11.4 & 11.5 & 11.5 & 11.6 & 11.7 & 11.8 & 11.9 & 11.9 & 11.9 \\
\hline & Expected years of schooling (years) & 12 & 14.7 & 16.6 & 16.7 & 16.8 & 16.8 & 16.8 & 17 & 16.8 & 16.8 & 16.8 \\
\hline & Education Index (EI) & 0.697 & 0.794 & 0.842 & 0.849 & 0.85 & 0.854 & 0.858 & 0.864 & 0.862 & 0.863 & 0.863 \\
\hline & GNI per capita in PPP terms (\$) & 19704 & 21521 & 25245 & 26292 & 27648 & 29101 & 29883 & 27369 & 27782 & 27152 & 26809 \\
\hline & Income Index (II) & 0.798 & 0.811 & 0.836 & 0.842 & 0.849 & 0.857 & 0.861 & 0.848 & 0.85 & 0.847 & 0.845 \\
\hline \multirow[t]{7}{*}{ Greece } & Life expectancy at birth (years) & 76.6 & 78.5 & 79.4 & 79.6 & 79.7 & 79.9 & 80.1 & 80.2 & 80.4 & 80.6 & 80.8 \\
\hline & Life Expectancy Index (LEI) & 0.871 & 0.901 & 0.914 & 0.917 & 0.919 & 0.921 & 0.924 & 0.927 & 0.929 & 0.932 & 0.935 \\
\hline & Mean years of schooling (years) & 7.9 & 8.6 & 9.8 & 9.9 & 10 & 10.1 & 10.1 & 10.2 & 10.2 & 10.2 & 10.2 \\
\hline & Expected years of schooling (years) & 12 & 14.2 & 16.8 & 17 & 16.5 & 16.5 & 16.5 & 16.5 & 16.5 & 16.5 & 16.5 \\
\hline & Education Index (EI) & 0.596 & 0.68 & 0.794 & 0.803 & 0.792 & 0.794 & 0.795 & 0.797 & 0.797 & 0.797 & 0.797 \\
\hline & GNI per capita in PPP terms (\$) & 21095 & 24334 & 28627 & 29828 & 30582 & 30271 & 29451 & 27831 & 26261 & 25507 & 24658 \\
\hline & Income Index (II) & 0.808 & 0.83 & 0.855 & 0.861 & 0.864 & 0.863 & 0.859 & 0.85 & 0.841 & 0.837 & 0.832 \\
\hline \multirow[t]{7}{*}{ Croatia } & Life expectancy at birth (years) & 72.3 & 74.8 & 75.5 & 75.7 & 75.9 & 76.1 & 76.4 & 76.5 & 76.7 & 76.9 & 77 \\
\hline & Life Expectancy Index (LEI) & 0.805 & 0.843 & 0.854 & 0.857 & 0.86 & 0.864 & 0.867 & 0.87 & 0.873 & 0.875 & 0.878 \\
\hline & Mean years of schooling (years) & 6 & 9.4 & 9.7 & 9.9 & 10.1 & 10.3 & 10.6 & 10.8 & 11 & 11 & 11 \\
\hline & Expected years of schooling (years) & 10.7 & 12.3 & 13.9 & 14 & 14.1 & 14.1 & 14.1 & 14.1 & 14.5 & 14.5 & 14.5 \\
\hline & Education Index (EI) & 0.497 & 0.656 & 0.708 & 0.719 & 0.729 & 0.737 & 0.744 & 0.76 & 0.77 & 0.77 & 0.77 \\
\hline & GNI per capita in PPP terms (\$) & 22303 & 14979 & 18409 & 19275 & 20352 & 20840 & 19286 & 19102 & 19555 & 19218 & 19025 \\
\hline & Income Index (II) & 0.817 & 0.757 & 0.788 & 0.795 & 0.803 & 0.807 & 0.795 & 0.793 & 0.797 & 0.794 & 0.793 \\
\hline \multirow[t]{7}{*}{ Montenegro } & Life expectancy at birth (years) & 74.5 & 74.1 & 73.7 & 73.8 & 74 & 74.2 & 74.3 & 74.5 & 74.6 & 74.7 & 74.8 \\
\hline & Life Expectancy Index (LEI) & 0.838 & 0.833 & 0.826 & 0.828 & 0.831 & 0.834 & 0.836 & 0.838 & 0.84 & 0.842 & 0.843 \\
\hline & Mean years of schooling (years) & & & 10.6 & 10.6 & 10.6 & 10.5 & 10.5 & 10.5 & 10.5 & 10.5 & 10.5 \\
\hline & Expected years of schooling (years) & & & 13.1 & 13.6 & 14.1 & 14.6 & 15 & 15.2 & 15.2 & 15.2 & 15.2 \\
\hline & Education Index (EI) & & & 0.717 & 0.73 & 0.744 & 0.757 & 0.768 & 0.774 & 0.774 & 0.774 & 0.774 \\
\hline & GNI per capita in PPP terms (\$) & 17483 & 10245 & 11233 & 12275 & 13500 & 14465 & 13426 & 13633 & 14241 & 14260 & 14710 \\
\hline & Income Index (II) & 0.78 & 0.699 & 0.713 & 0.727 & 0.741 & 0.751 & 0.74 & 0.742 & 0.749 & 0.749 & 0.754 \\
\hline \multirow[t]{7}{*}{ Rumania } & Life expectancy at birth (years) & 69.5 & 70.5 & 72.4 & 72.7 & 72.9 & 73.1 & 73.3 & 73.5 & 73.6 & 73.7 & 73.8 \\
\hline & Life Expectancy Index (LEI) & 0.762 & 0.776 & 0.805 & 0.81 & 0.814 & 0.818 & 0.82 & 0.823 & 0.825 & 0.826 & 0.828 \\
\hline & Mean years of schooling (years) & 9 & 9.9 & 10.1 & 10.3 & 10.4 & 10.5 & 10.5 & 10.6 & 10.7 & 10.7 & 10.7 \\
\hline & Expected years of schooling (years) & 12.1 & 11.7 & 13.4 & 13.5 & 13.8 & 14.3 & 14.5 & 14.2 & 14.1 & 14.1 & 14.1 \\
\hline & Education Index (EI) & 0.637 & 0.654 & 0.709 & 0.717 & 0.732 & 0.748 & 0.754 & 0.747 & 0.748 & 0.748 & 0.748 \\
\hline & GNI per capita in PPP terms (\$) & 11295 & 9796 & 13363 & 14523 & 15607 & 17260 & 16452 & 16401 & 16825 & 16806 & 17433 \\
\hline & Income Index (II) & 0.714 & 0.693 & 0.739 & 0.752 & 0.763 & 0.778 & 0.771 & 0.77 & 0.774 & 0.774 & 0.78 \\
\hline \multirow[t]{7}{*}{ Bulgaria } & Life expectancy at birth (years) & 71.3 & 71.4 & 72.6 & 72.7 & 72.9 & 73 & 73.1 & 73.2 & 73.3 & 73.4 & 73.5 \\
\hline & Life Expectancy Index (LEI) & 0.789 & 0.791 & 0.809 & 0.811 & 0.813 & 0.816 & 0.817 & 0.819 & 0.821 & 0.822 & 0.824 \\
\hline & Mean years of schooling (years) & 8.9 & 9.5 & 10 & 10.1 & 10.2 & 10.4 & 10.5 & 10.6 & 10.6 & 10.6 & 10.6 \\
\hline & Expected years of schooling (years) & 12.1 & 12.9 & 13.5 & 13.5 & 13.8 & 13.8 & 13.9 & 14.2 & 14.3 & 14.3 & 14.3 \\
\hline & Education Index (EI) & 0.632 & 0.676 & 0.71 & 0.713 & 0.725 & 0.728 & 0.735 & 0.747 & 0.749 & 0.749 & 0.749 \\
\hline & GNI per capita in PPP terms (\$) & 8869 & 8994 & 12761 & 13262 & 13611 & 15009 & 14501 & 14695 & 14793 & 15178 & 15402 \\
\hline & Income Index (II) & 0.678 & 0.68 & 0.732 & 0.738 & 0.742 & 0.757 & 0.752 & 0.754 & 0.755 & 0.759 & 0.761 \\
\hline
\end{tabular}




\begin{tabular}{|c|c|c|c|c|c|c|c|c|c|c|c|c|}
\hline \multirow[t]{7}{*}{ Turkey } & Life expectancy at birth (years) & 64.3 & 70 & 72.5 & 72.9 & 73.2 & 73.6 & 73.9 & 74.3 & 74.6 & 74.9 & 75.3 \\
\hline & Life Expectancy Index (LEI) & 0.681 & 0.769 & 0.807 & 0.813 & 0.819 & 0.824 & 0.83 & 0.835 & 0.84 & 0.845 & 0.85 \\
\hline & Mean years of schooling (years) & 4.5 & 5.5 & 6 & 6.1 & 6.2 & 6.5 & 6.6 & 7.2 & 7.4 & 7.6 & 7.6 \\
\hline & Expected years of schooling (years) & 8.9 & 11.1 & 11.9 & 12.3 & 12.6 & 12.5 & 13 & 13.9 & 14.4 & 14.4 & 14.4 \\
\hline & Education Index (EI) & 0.398 & 0.493 & 0.531 & 0.545 & 0.557 & 0.653 & 0.582 & 0.625 & 0.648 & 0.652 & 0.652 \\
\hline & GNI per capita in PPP terms (\$) & 10546 & 12890 & 15060 & 15886 & 16444 & 16343 & 15330 & 16587 & 17814 & 18011 & 18391 \\
\hline & Income Index (II) & 0.704 & 0.734 & 0.757 & 0.766 & 0.771 & 0.77 & 0.76 & 0.772 & 0.783 & 0.785 & 0.788 \\
\hline \multirow[t]{7}{*}{ Serbia } & Life expectancy at birth (years) & 71.5 & 72.1 & 72.8 & 73 & 73.2 & 73.4 & 73.5 & 73.7 & 73.8 & 73.9 & 74.1 \\
\hline & Life Expectancy Index (LEI) & 0.792 & 0.801 & 0.813 & 0.816 & 0.818 & 0.821 & 0.824 & 0.826 & 0.828 & 0.83 & 0.832 \\
\hline & Mean years of schooling (years) & 8 & 9.2 & 9.4 & 9.4 & 9.5 & 9.5 & 9.5 & 9.5 & 9.5 & 9.5 & 9.5 \\
\hline & Expected years of schooling (years) & 13.6 & 13.6 & 13.6 & 13.6 & 13.6 & 13.7 & 13.7 & 13.6 & 13.6 & 13.6 & 13.6 \\
\hline & Education Index (EI) & 0.646 & 0.686 & 0.691 & 0.692 & 0.693 & 0.697 & 0.697 & 0.695 & 0.695 & 0.695 & 0.695 \\
\hline & GNI per capita in PPP terms (\$) & 14264 & 7820 & 10122 & 10513 & 11044 & 11435 & 11194 & 11287 & 11445 & 11030 & 11301 \\
\hline & Income Index (II) & 0.749 & 0.658 & 0.697 & 0.703 & 0.711 & 0.716 & 0.713 & 0.714 & 0.716 & 0.71 & 0.714 \\
\hline \multirow[t]{7}{*}{ Macedonia } & Life expectancy at birth (years) & 71.1 & 73.2 & 74.1 & 74.2 & 74.3 & 74.5 & 74.6 & 74.7 & 74.9 & 75 & 75.2 \\
\hline & Life Expectancy Index (LEI) & 0.787 & 0.819 & 0.832 & 0.834 & 0.836 & 0.838 & 0.84 & 0.842 & 0.844 & 0.847 & 0.849 \\
\hline & Mean years of schooling (years) & & & 8.2 & 8.2 & 8.2 & 8.2 & 8.2 & 8.2 & 8.2 & 8.2 & 8.2 \\
\hline & Expected years of schooling (years) & 10.6 & 11.6 & 11.7 & 11.9 & 12.1 & 13.1 & 13.2 & 13.3 & 13.3 & 13.3 & 13.3 \\
\hline & Education Index (EI) & & & 0.597 & 0.603 & 0.609 & 0.636 & 0.639 & 0.642 & 0.642 & 0.642 & 0.642 \\
\hline & GNI per capita in PPP terms (\$) & 10050 & 8906 & 9407 & 10065 & 10195 & 11100 & 11024 & 11284 & 11554 & 11417 & 11745 \\
\hline & Income Index (II) & 0.696 & 0.678 & 0.687 & 0.697 & 0.699 & 0.711 & 0.71 & 0.714 & 0.717 & 0.716 & 0.72 \\
\hline \multirow[t]{7}{*}{ Bosnia-Herzegovina } & Life expectancy at birth (years) & 67.2 & 74.9 & 75.2 & 75.3 & 75.5 & 75.6 & 75.8 & 75.9 & 76.1 & 76.2 & 76.4 \\
\hline & Life Expectancy Index (LEI) & 0.726 & 0.844 & 0.85 & 0.851 & 0.853 & 0.856 & 0.858 & 0.86 & 0.862 & 0.865 & 0.867 \\
\hline & Mean years of schooling (years) & & & 8.7 & 8.6 & 8.5 & 8.5 & 8.4 & 8.3 & 8.3 & 8.3 & 8.3 \\
\hline & Expected years of schooling (years) & 13.1 & 13.1 & 13.1 & 13.1 & 13.1 & 13.3 & 13.3 & 13.4 & 13.6 & 13.6 & 13.6 \\
\hline & Education Index (EI) & & & 0.653 & 0.651 & 0.648 & 0.652 & 0.649 & 0.65 & 0.655 & 0.655 & 0.655 \\
\hline & GNI per capita in PPP terms (\$) & 1508 & 6707 & 8006 & 8430 & 9003 & 9548 & 9299 & 9254 & 9345 & 9304 & 9431 \\
\hline & Income Index (II) & 0.41 & 0.635 & 0.662 & 0.67 & 0.68 & 0.689 & 0.685 & 0.684 & 0.685 & 0.685 & 0.687 \\
\hline \multirow[t]{7}{*}{ Albania } & Life expectancy at birth (years) & 71.8 & 74.2 & 75.9 & 76.1 & 76.3 & 76.4 & 76.6 & 76.8 & 77 & 77.2 & 77.4 \\
\hline & Life Expectancy Index (LEI) & 0.798 & 0.834 & 0.861 & 0.863 & 0.866 & 0.868 & 0.871 & 0.874 & 0.877 & 0.88 & 0.883 \\
\hline & Mean years of schooling (years) & 7.4 & 8.5 & 8.8 & 8.9 & 8.9 & 9 & 9 & 9.1 & 9.3 & 9.3 & 9.3 \\
\hline & Expected years of schooling (years) & 10.5 & 10.1 & 10.8 & 10.8 & 10.8 & 10.8 & 10.8 & 10.8 & 10.8 & 10.8 & 10.8 \\
\hline & Education Index (EI) & 0.537 & 0.565 & 0.595 & 0.596 & 0.598 & 0.6 & 0.601 & 0.602 & 0.609 & 0.609 & 0.609 \\
\hline & GNI per capita in PPP terms (\$) & 3257 & 5185 & 6921 & 7373 & 7867 & 8351 & 8401 & 8706 & 9075 & 9069 & 9225 \\
\hline & Income Index (II) & 0.526 & 0.596 & 0.64 & 0.65 & 0.659 & 0.668 & 0.669 & 0.675 & 0.681 & 0.681 & 0.683 \\
\hline
\end{tabular}

Source: UNDP

Referring Income Index, Slovenia leads the list with a value of 0.845 , which is followed by Greece with a value of 0.832 . Albania has the lowest value of this index, respectively 0,683 . The most important indicator to measure the welfare of the people is the national income per capita expressed in Purchasing Power Parity (PPP Purchasing Power Parity) in USD \$. To make the data comparable between countries, firstly the data must be converted into a common currency such as USD \$. Unlike market exchange rates, PPP conversion rates allow this conversion taking into account the price changes between countries. In this way GNI per capita (PPP) better reflects the people's living standards. If we compare the GNI per capita in the region Albania ranks last with a GNI per capita of $9,225 \$$ which is approximately one third of GNI per capita of Slovenia and less than half of Croatia (before its stays Bosnia-Herzegovina with 9,431 \$, Serbia with 11,301 \$, Macedonia with 11,745 \$, Montenegro 14,710 \$, Bulgaria with 15,402 \$ and Romania with 17,658 \$). Meanwhile, in the first place is ranked Slovenia $(26,809 \$)$, followed from Greece $(24,658 \$)$, Croatia $(19,025 \$)$ and Turkey $(18,391 \$)$. In general, income index has improved over the period of time 1990-2008. Today it is accepted that the global economic crisis affected the Balkan region, where economic activity was slowed significantly after 2008. In general, the data showed that the growth rate was declining during 2008-2013 reflected this decline in income per capita.

\section{Discussion}

In the recent years we have observed the emergence of a large literature on new indicators of welfare and quality of life. This paper has stressed the importance of improving the welfare measure being shifted from the traditional measure that 
focus only on the economic aspects towards a multidimensional measure which includes social aspects other than economic ones, suggesting that efforts to develop new measurement of welfare and enjoyment of life are necessary for policymakers who can formulate effective policies and can be focused more on improving the welfare of the people not only in income growth. The latest attempt to assess the welfare and human progress is based on the use of a multidimensional measure which combines different indicators of socio-economic development. One of the most successful and widely measures is Human Development Index which is used by UNDP since 1990 and reoriented assessment, understanding and measuring of human development.

\section{Conclusions}

This paper has analyzed various aspects of human development in the Balkan countries (with the exception of Kosovo, due to the limited resources of data) based on data from UNDP through a qualitative comparative analysis. The successive Reports of Human Development have shown that most Balkan countries have had an improvement in human development aspects. Fastest pace of growth were recorded in the period 2000-2008 than in the period 1990-2000. Most of the countries in the region have experienced a slowdown in growth rates of $\mathrm{HDI}$ after 2008 and this is connected with the global economic and financial crisis which seems to have a wider impact. The list of countries in the region that are taken into analysis has led Slovenia, which is positioned in 25th place with a HDI value of 0.874 which was followed by Greece (29) and Croatia (47), Montenegro (51), Romania (54), Bulgaria (58), Turkey (69), Serbia (77), Macedonia (84) and Bosnia-Herzegovina (86) and Albania is ranked last in the region with a HDI value of 0.716 which is positioned in 95th place. In terms of life expectancy index has had a significant improvement of this index and Greece has the highest value while Bulgaria has the-smallest value. Slovenia has the highest values of the education and income indices. While Albania is at the end related to the values of education and income indices.

\section{References}

Anand, S, and Sen, A. (2000). "The Income Component of the Human Development Index", Journal of Human Development, 1(1), 83106.

Anand, S. \& Sen, A. (1992). "Human Development Index: Methodology and Measurement", Human Development Report Office Occasional Paper No. 12, New York: UNDP.

Bauer, R. A. (1966). Social indicators. Cambridge: MIT Press.

Bertschy, K. Boni, E. \& Meyer, T. (2008), "Young People in Transition from Education to Labour Market", result of the Swiss youth panel survey.

Camp, S. L. \& Speidel, J. J. (1987). The International Human Suffering Index. Washington: Population Crisis Committee.

Campbell, A., Converse, P., \& Rodgers, W. (1976). The quality of American life: Perceptions, evaluations and satisfactions. New York: Russell Sage Foundation.

Desai, M. (1993). Income and alternative measures of well-being. In Westendorff, D and Ghai, D Monitoring Social Progress in the 1990s, Avebury: UNRISD.

Drewnowski, J. \& W. Scott (1966). "The Level of Living Index", United Nations Research Institute for Social Development (UNRISD). Report No. 4, Geneva: United Nations

Estes, J. R, (2012), "Global change and indicators of social development", Weil, M., Reisch, M. \& Ohmer, L.M (Editors), The Handbook of Community Practice, 2nd Edition, 587-606, Sage Publications .

Haq, M.U. (1995). Reflections on Human Development. New York: Oxford University Press.

Hicks, N. \& Streeten, P. (1979). "Indicators of development: The search for a basic needs yardstick", World Development, 7: 567-580.

McGillivray, M \& Noorbakhsh, F. (2004). "Composite Indices of Human Well-being: Past, Present, and Future". World Institute for Development Economic Research (WIDER), Research Paper No. 63. United Nations University.

McGranahan, D. V., C. Richard-Proust, N. V. Sovani \& M. Subramanian (1972). "Contents and Measurement of Socio-economic Development". A Staff Study of the United Nations Research Institute for Social Development(UNRISD). New York: Praeger.

Morris, D. (1979). Measuring the World's Poor: The Physical Quality of Life Index, Pergamon Press, New York.

Nayk, P. (2013), "Methodological Developments in Human Development Literature", MPRA Paper No. 51192.

Noorbakhsh, F. (1998a). "The human development index: Some technical issues and Alternative indices", Journal of International Development, 10(5), 589-605.

Noorbakhsh, F. (1998b). "A Modified Human Development Index", World Development, 26(3), 517-528.

Ranis, G.,( 2004)."Human Development and Economic Growth", Economic Growth Center, Discussion Paper No. 887, Yale University.

Seers, D. (1972). "What are we trying to measure?", The Journal of Development Studies, 8(3).

Sen, A. (1984). Resources, Values and Development. Oxford: Basil Blackwell.

Stiglitz, J., Sen, A., \& Fitoussi, J. (2009). Report by the Commission on the Measurement of Economic Performance and Social Progress. Paris. 
Srinivasan, T. N. (1994). "Human Development: A New Paradigm or Reinvention of the Wheel?", American Economic Review, Papers and Proceedings, 84(2): 238-243.

Stanton , A. E (2007). "The Human Development Index: A History", Amherst: Political Economy Research Institute (PERI) Working Papers Series Nr.127, University of Massachusetts.

Streeten, P. (1994). Human Development: Means and Ends, American Economic Review, Papers and Proceedings, 84(2): 232-237.

Streeten, P., Burki, J. S., Haq, M.u., Hicks, N. \& Stewart, F. (1981). First Things First: Meeting Basic Human Needs in Developing Countries. Oxford University Press, New York.

Trésor-Economics (2009). "Measuring economic performance and social progress: the findings of the Stiglitz-Sen-Fitoussi Commission", No. 67 .

United Nations (1954). Report on International Defnition and Measurement of Standards and Levels of Living. New York: United Nations.

United Nations Research Institute for Social Development (UNRISD) (1972). Contents and Measurement of Socio-economic Development. Praeger Publishers, New York.

United Nations Development Programme (UNDP). Human Development Reports 1990-2014. UNDP. New York. UNDP data: www.hdr.undp.org; http://hdr.undp.org/en/data; http://hdr.undp.org/en/countries

UNDP.(1990). "Concept and Measurement of Human Development". Human Development Report. UNDP. New York.

UNDP. (2013). "The Rise of the South: Human Progress in a Diverse World". Human Development Report. UNDP. New York.

UNDP. (2014). "Sustaining Human Progress: Reducing Vulnerability and Building Resilience". Human Development Report. UNDP. New York. 